\title{
Down Syndrome : Report of a Cytogenetic Study and a New Proposed Practical Classification
}

\author{
Wahyuning Ramelan
}

\begin{abstract}
Abstrak
Sindrom Down merupakan kelainan genetik yang paling sering dijumpai, yang disebabkan oleh kelainan jumlah kromosom atau aberasi numerik, yaitu trisomi-21. Secara sitogenetik, kelainan ini dapat menampilkan berbagai aberasi kromosom. Klasifikasi sindrom ini yang ada sekarang didasarkan pada keadaan kromosomnya, terasa kurang praktis, terutama untuk konseling, sehingga dapat dikatakan tidak berguna. Makalah ini menyampaikan hasil pemeriksaan sitogenetik pada 280 penderita sindrom Down. Berdasarkan hasil pemeriksaan itu, diusulkan klasifikasi baru yang hanya terdiri dari 4 kelompok, yang lebih praktis sehingga lebih bermanfaat, yaitu: Sindrom Down reguler atau primer, sindrom Down translokasi atau sekunder dan sindrom Down mosaik atau tersier serta sindrom Down lain atau kuarterner. Empat kelompok sindrom Down menurut klasifikasi ini, hampir sejalan dengan 4 kelas sindrom Down menurut International Classification of Diseases yang terbaru dari WHO (WHO-ICD 10).
\end{abstract}

\begin{abstract}
Down syndrome is the most frequent genetic abnormality, with numerical chromosome aberration (namely trisomy-21) as the aetiology. Cytogenetically, this disease has many types of chromosome aberrations. The existing classification based on the chromosome picture, is not very practical, especially for counseling, and hence not very beneficial. This paper reports 280 cases of Down syndrome which had been examined cytogenetically. In correlation with the results, this paper proposes a new, more beneficial and practical classification of Down syndrome. This proposed classification consists only of 4 groups : Regular or primary Down syndrome, translocation or secondary Down syndrome, mosaic or tertiary Down syndrome, and other types or quarternary Down Syndrome. The existence of 4 groups of Down syndrome in this new proposed classification fits the newest International Classification of Diseases of the WHO (WHO-ICD 10) quite well.
\end{abstract}

Keywords : Down syndrome, cytogenetic study, cytogenetic classification.

\section{INTRODUCTION}

Down syndrome (DS) is the most frequent genetic abnormality with numerical chromosome aberration (namely trisomy 21 ) as the aetiology. ${ }^{1}$ The syndrome was named after Dr. Langdon Down, who in 1866 reported a syndrome of mental deficiency. The facial appearance of the patient, resembles the face of the people of the Mongol race. The likeness is undependent to the race of the patient. Once you have seen a patient with DS you will always recognize other cases, even in patients of other races. Because of the abnormal mongoloid-like 'facies', he named the syndrome mongolism or mongoloid idiocy. ${ }^{2}$ Because the name sounded very racial, it was then named Down syndrome. ${ }^{1}$ Nearly a century went by before its nature could be concealed, although Waardenburg in 1932 and Penrose in 1939 had suggested the possibility of chromosome abnormalities as the aetiology. ${ }^{1,2}$

Mittwoch in 1952 studied meiosis of male patients with DS, and found 24 bodies/chromosomes. ${ }^{2}$ Her conclusion of human meiotic chromosome number as $\mathbf{2 4}$ and made the diploid number of 48 in human, made it farther from the nature of DS. It was Lejeune in 1959 who showed the actual existence of chromosome aberration in DS which later was also confirmed by others. ${ }^{2}$

Down syndrome can occur in the male as well as in the female, it can be found all over the world and it is not restricted to any race or any season. In general 
the incidence is 1 out of $700-800$ newborns, or 1 in $900-1000$ of the general population. ${ }^{1,3}$ Epidemiologically, about $95 \%$ of the cases, are influenced by the maternal age at conception. Recently, a higher percentage of dependancy to mother age was also confirmed by Antonarakis et al. ${ }^{4}$ Using DNA polymorphisms, they got 188 DS patients with an extra chromosome21 from the mother, compared to only 9 DS with an extra chromosome-21 which was paternally derived. The relative risk of a mother to give birth to a baby with DS increases slowly until the age of 30 years, rather fast after the age of 30 and it becomes much faster after 35 year of age, as shown in Figure 1.

From logical thinking, family with a DS child can be thought as has a kind of burden, and will not be happy or satisfied with their life. Branholm and Degerman $^{5}$ showed the opposite of it. Most of the families with a DS child, as their study subjects, remain to have their satisfaction with life. Both researcher interpreted those satisfaction as a result of adequate adaptive resources.
Now we know that there are many types of chromosome aberrations in DS. Cytogenetically DS or trisomy-21 was classified in several groups. The classification is not practical, especially for counselling. In correlation with the newest International Classification of Diseases of the WHO (WHO ICD 10), the existing classifications are not well matched. A more practical DS classification should be made and used.

The purpose of this study is to compare the cytogenetic condition found in the DS patients in Jakarta to DS patients in general population (literature), and to put forward a new classification of DS macthing with the WHO-ICD 10 , which is more practical and hence more beneficial especially for genetic counseling.

\section{MATERIALS AND METHODS}

Patients clinically diagnosed as suspected Down syndrome were subjected to cytogenetic examination at our laboratory of the Section of Medical Genetics,

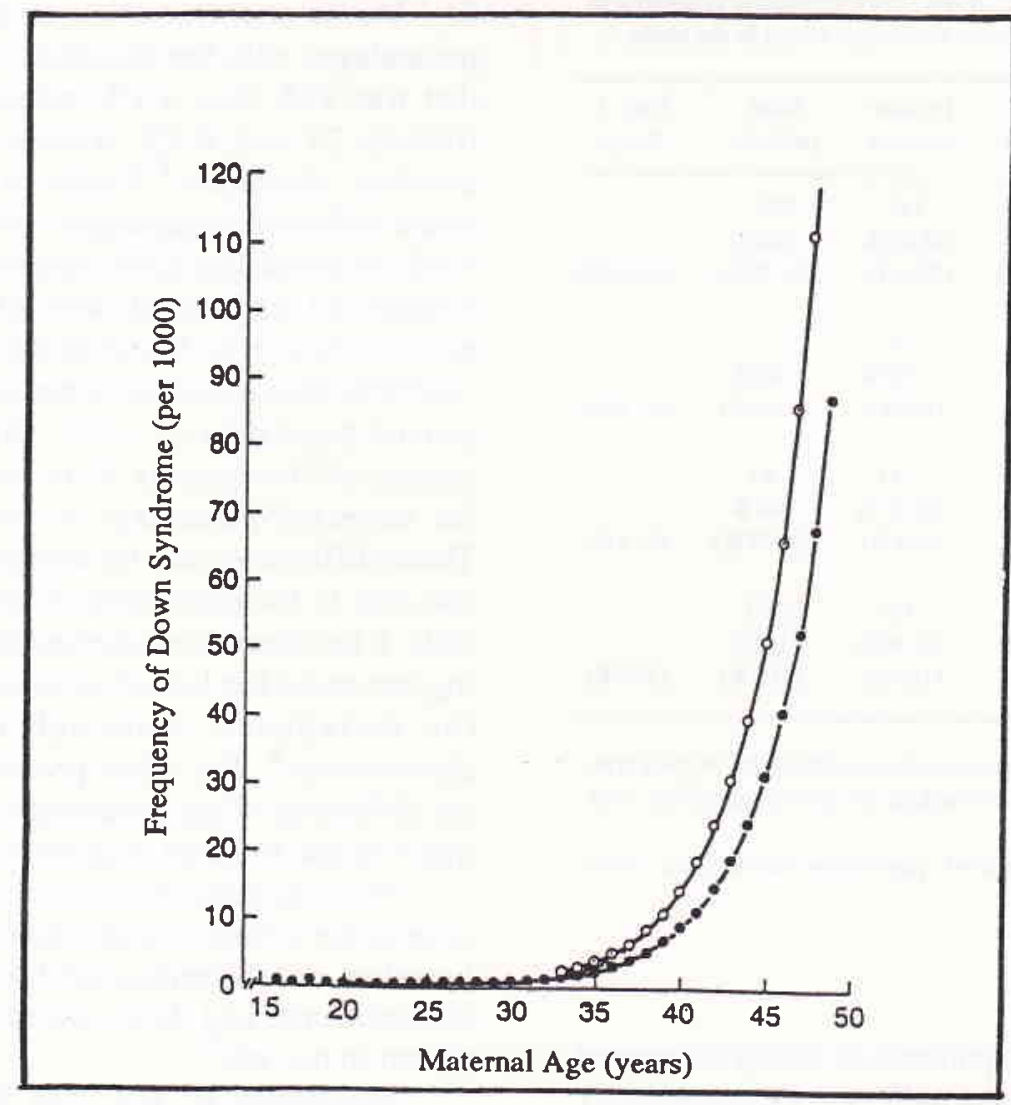

Figure 1. The relative incidence of (risk to have) Down syndrome according to maternal age (from Epstein), ${ }^{7}$ circle $=$ at the time of amniocentesis, solid dot $=$ at birth 
Department of Medical Biology Faculty of Medicine, University of Indonesia. There were 283 patients suspected of Down syndrome, examined cytogenetically over a period of 6 years (1989 - 1994).

The cytogenetic examination performed was chromosome analysis. The method used was the modified method of Moorhead. The cell preparation was stained and then examined morphologically.

\section{RESULTS}

Three from the 283 patients showed normal $46, \mathrm{XY}$ or $46, \mathrm{XX}$ karyotype. The remaining 280 patients, consisting of 125 females and 155 males, were cytogenetically confirmed as trisomy 21 . As predicted, most of them were $47, X Y$ or $47, X Y$ with an additional free chromosome-21 (229 patients or $81.79 \%$ ). Four patients (1.43\%) had Robertsonian translocation to $G$ chromosome ( 3 patients) and to D chromosome (one patient). The rest (47 patients or $16.78 \%$ ) had mosaicism or mixoploid $(46, \mathrm{XX} / 47, \mathrm{XX},+21$ or 46,XY/47,XY,+21) (Table 1).

Table 1. Number and percentage ${ }^{\star}$ of the Down syndrome according to sex and type of chromosome aberration found in the study

\begin{tabular}{ccccc}
\hline $\begin{array}{l}\text { Type of chromo- } \\
\text { some aberration }\end{array}$ & $\begin{array}{c}\text { Male } \\
\text { paticnts }\end{array}$ & $\begin{array}{c}\text { Female } \\
\text { patients }\end{array}$ & $\begin{array}{c}\text { Total } \\
\text { patients }\end{array}$ & $\begin{array}{c}\text { Exp. } \dagger \\
\% \text {-age }\end{array}$ \\
\hline $47, \mathrm{XX}$ or XY, +21 & 117 & 112 & 229 & \\
& $51.09 \%$ & $48.91 \%$ & $100 \%$ & \\
& $(75.48 \%)$ & $(89.6 \%)$ & $(81.79 \%)$ & $(93-96 \%)$ \\
$46, \mathrm{XX}$ or $46, \mathrm{XY},+21$ & 2 & 2 & 4 & \\
$+\mathrm{t}(\mathrm{D}: 21)$ or t(G:21) & $50 \%$ & $50 \%$ & $100 \%$ & \\
& $(1.29 \%)$ & $(1.6 \%)$ & $(1.43 \%)$ & $(2-5 \%)$ \\
$46, \mathrm{XX} / 47, \mathrm{XY},+21$ or & 36 & 11 & 47 & \\
$46, \mathrm{XY} / 47, \mathrm{XY},+21$ & $76,59 \%$ & $23.41 \%$ & $100 \%$ & \\
& $(23.23 \%)$ & $(8.8 \%)$ & $(16.78 \%)$ & $(2-4 \%)$ \\
Total & 155 & 125 & 280 & \\
& $55.36 \%$ & $44.64 \%$ & $100 \%$ & \\
& $(100 \%)$ & $(100 \%)$ & $(100 \%)$ & $(100 \%)$ \\
\hline
\end{tabular}

* percentages without brackets are percentage of the total in each type of aberration and percentages in brackets are percentage of the total female/male group.

texpected percentage in a general population (corrected), from Epstein.?

\section{DISCUSSION}

Only $3(1.06 \%)$ out of 283 patients clinically diagnosed as suspected DS were not confirmed cytogenetically as DS. Our clinical accuracy is high compared to Cortes et $\mathrm{al}^{6}$ from Chili with $11 \%$ (22 out of 201 patients) misdiagnosed as DS.
As known very well, DS can occur in the male as well as in the female. This means that the incidence of this abnormality is the same in male and in female. The number of DS in this study is very different in male and female patients (155 and 125 respectively), but the ratio of male to female patients with DS found in our report $(1.24: 1.0)$ is not too different from Chili ${ }^{6}$ with ratio of $(1.18: 1.0)$. In our study rough calculation of the $\mathrm{X}^{2}$ for the difference between male and female is $>3$. This can be interpreted as significantly different. This can be the result of an actual difference of DS incidence in the general population, or a lower compatibility to survive in the female compared to male DS patients. Another possible explanation for the difference in this study might be the different attitude of our society toward male and female DS patients. Our society cares and hopes for betterment in the male more than they do for the female DS patients. Further study should be done to ensure which one of those possibilities is the right one.

Table 1 shows that the percentage of each group of DS is rather different from the expected in general population. Epstein in his review had $93-96 \%$ regular or free, $2-5 \%$ translocation and $2-4 \%$ mosaic trisomy $21{ }^{7}$ Verma et al from New Delhi have rather similar percentages with the expected in general population, that was $93 \%$ free, $4.1 \%$ translocation, $2.6 \%$ mosaic trisomy 21 and $0.3 \%$ trisomy 21 with other concomitant aberration. ${ }^{8}$ Cortes et al from Chili found rather different percentages : $89,9 \%$ classic or free $3.9 \%$ translocation, $2.8 \%$ mosaic trisomy 21 and $3.4 \%$ trisomy 21 associated with other aberration. ${ }^{6}$ The mosaic trisomy 21 found in this study is much higher $(16.78 \%)$ than expected in corrected percentage of the general population $(2-4 \%)$. Correlationally, the percentage of free trisomy 21 is lower in this study, than the corrected percentage in the general population. Those differences can be interpreted as laboratory errors due to the processing of the slide preparation of cells. It has been shown before that laboratory processing can cause the lost of an individual chromosome of the metaphase, although more of the small chromosome ${ }^{9}$. The other possibility that can explain the difference of the percentage found in this study is that it is due to racial or genetic reason.

From the theoretical point of view, mosaicism can arise in the mitotic cell division, post-zygotic non-disjunction or chromosome lost. In vitro study of chromosome lost from normal subjects has been shown in our lab. ${ }^{9}$

Mosaicism of DS can begin from a normal $46, \mathrm{XX}$ or $46, \mathrm{XY}$ zygote. During the early cleavage a cell divides and yields to daughter cells with trisomy 21 and monosomy 21 , followed by death of the 
monosomy 21 cells. The blastocyst then will consisted of normal $46, \mathrm{XX}$ or XY cells and trisomy 21 cells. Another possibility is that a mosaic DS can arise from a trisomy 21 zygote. Lost of one of the free chromosome 21 during mitotic division in the early period of embryo yield to daughter cells, one with trisomy and the other one with normal chromosomes (Figure 2). Which one of those 2 possibilities results in mosaic DS, should be investigated. The result of this study, a higher number of mosaicism in the male, needs explanation. An explanation for this maybe that nondisjunction (for zygote with 46 chromosome) or lost of chromosome during mitotic division (for $47,+21$ zygote) happens more easily in zygote with $Y$ chromosome.

\section{Cytogenetic classification of Down syndrome}

Hamerton $^{2}$ has proposed a cytogenetic classification of DS : primary, secondary, mixoploid or mosaic trisomy 21 , double trisomy ( 21 with other type of trisomies), primary G (21) tetrasomy and normal phenotype subjects with translocation of chromosome
21 to either $D[t(D ; 21)]$ or $G$ chromosome $[t(21 ; G)]$ (Table 2). Primary $\mathrm{G}$ tetrasomy and double trisomy are very rare. The inclusion of normal phenotype subjects with $t(D ; 21)$ and $t(21 ; G)$ in the DS classification provoked many questions.

De Grouchy and Turleau ${ }^{10}$ also classified (although not explicitly) the DS cytogenetically, the groups being : free, translocation, mosaic, partial and association trisomy 21 (Table 2). All kinds of double trisomies belonged to the last group. Partial and association trisomy 21 are also very rare. So a more simple and practical cytogenetic classifcation of DS should be proposed and used.

\section{A new proposed cytogenetic classification of Down Syndrome}

As seen in table 1, most of the subjects with DS belong to free additional chromosome 21 , so primary or regular DS still can be used efficiently. According to Epstein, about $95 \%$ of DS patients belong to this class. ${ }^{7}$

Primary or regular DS means that the chromosome condition is $47, \mathrm{XX},+21$ or $47, \mathrm{XY},+21$. All

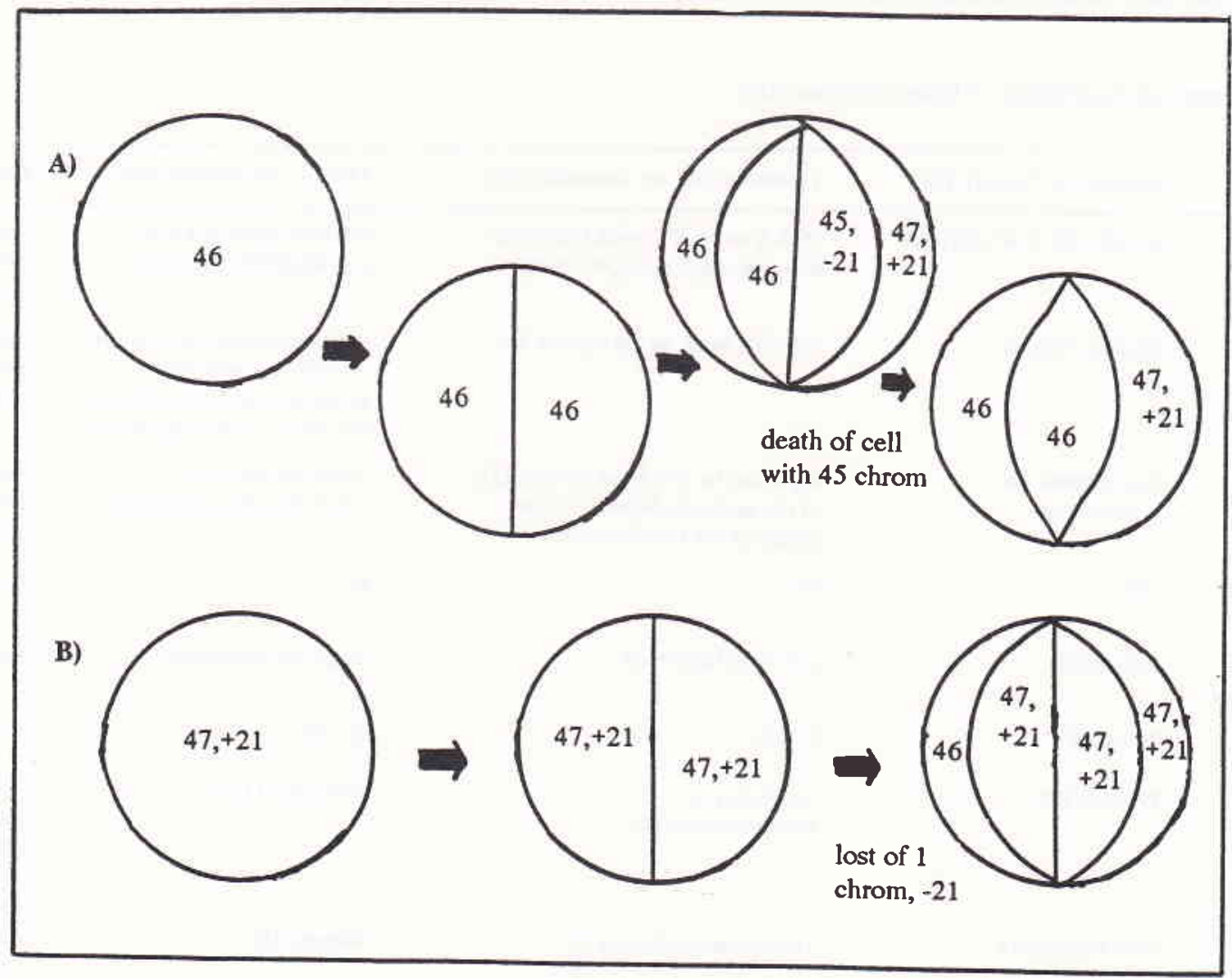

Figure 2. The tertiary or mosaic Down syndrome, began from :

A) a normal $46, X X$ or $46, X Y$ zygote and

$B)$ an already trisomy 21 zygote, $(X X$ or $X Y)$ 
patients with regular or primary DS have the similarity that their parents were normal cytogenetically. Still further, the recurrence risk of this abnormality is almost stable, doesn't increase drastically. The risk does increase but still correlate with the increasing age of the mother, which conform to general population. The clinical picture of these patients are typical, classical or standards.

Secondary or translocation DS also still can be used, although a litle bit rare. Only $2-5 \%$ of the patients with DS can be categorized in this class. Although the nature of the translocations is different, there is still a similarity in that one of the parent has the same chromosomal translocation as the DS patient has, but the parent has no additional chromosome (balanced translocation). The recurrence risk of this type of DS is increased drastically. The risk could be very high up to $100 \%$ in $21-21$ translocation in the mother. Patients belonging to this category have the same clinical picture as the regular or primary DS.

Tertiary or mosaic DS can be proposed and used for DS patients with mosaicism or mixoploid condition of their chromosome number. Although this group of DS is also rather rare (almost the same as the secondary
DS), ${ }^{7}$ they still can be grouped into one. They have these similarities : their parents are cytogenetically normal and they still have cells with normal, disomic chromosome number (46). The recurrence risk of this condition is very low, may be much lower than the primary DS. Of all the patients with DS, mosaic DS has a broad range of clinical picture. They can appear clinically normal, but they can also appear as primary DS. The proportion and bodily distribution of the trisomic cells play an important role in this clinical picture.

Quarternary DS is a new category for any kind of cytogenetic conditon other than those already categorized above. This kind of DS is clearly below $1 \%$ in frequency and might be under $5 \%$ o. As shown in this study, from 280 patients with confirmed DS no patient can be categorized in this group. The chromosome aberration of a patient in this group should be stated clearly. For instance, a double trisomy of Klinefelter syndrome and DS, should be followed by its cytogenetic nature i.e. $48, \mathrm{XXY},+21$.

All those characteristics of the DS for each group of the new proposed classification, which already ilustrated, are briefly summarized in table 2 .

Table 2. A new proposed classification of Down syndrome (DS)

\begin{tabular}{|c|c|c|c|c|}
\hline DS classific. & Regular or Primary DS & Translocation or Secondary DS & Mosaic or Tertiary DS & Quarternary DS \\
\hline Chromosome & $47, X X,+21$ or $47, X Y,+21$ & $\begin{array}{l}46, X X \text { or } 46, X Y, \text { with transloca- } \\
\text { tion, e.g. } 46, X Y,-13,+t(13 ; 21)\end{array}$ & $\begin{array}{l}\text { has } 2 \text { or more cell line } \\
\text { e.g. } 46, X X / 47, X X,+21\end{array}$ & $\begin{array}{l}\text { other type, does } \\
\text { not belong } \\
\text { to other groups }\end{array}$ \\
\hline Clinical picture & specific, typical & specific, same as the regular DS & $\begin{array}{l}\text { variable appearence, can be } \\
\text { normal as a non Down } \\
\text { syndrome and can also be } \\
\text { the same as the regular one }\end{array}$ & $\begin{array}{l}\text { variable, } \\
\text { same as the } \\
\text { mosaic DS }\end{array}$ \\
\hline Recurrence risk & $\begin{array}{l}\text { low, depend on } \\
\text { mother's age }\end{array}$ & $\begin{array}{l}\text { high, can be } 100 \% \text { [as in }(21 ; 21) \\
\text { of the mother], depend on the } \\
\text { nature of the translocation }\end{array}$ & $\begin{array}{l}\text { might be very low, } \\
\text { lower than the regular DS }\end{array}$ & $\begin{array}{l}\text { very low, } \\
\text { lower than the } \\
\text { tertiary DS }\end{array}$ \\
\hline $\begin{array}{l}\text { Dependancy } \\
\text { on mother's age }\end{array}$ & yes & no & no & no \\
\hline $\begin{array}{l}\text { Chromosome } \\
\text { analysis in parent }\end{array}$ & no benefit & yes; very important & might be benelicial & might be beneficial \\
\hline Frequency * & $92-96 \%$ & $2-5 \%$ & $2-4 \%$ & $<1 \%$ \\
\hline $\begin{array}{l}\text { Hamerion's } \\
\text { Classific. } †\end{array}$ & Primary DS & $\begin{array}{l}\text { Secondary or } \\
\text { Translocations DS }\end{array}$ & Mixoploid DS & $\begin{array}{l}\text { - Primary G } \\
\text { tetrasomy } \\
\text { - Double trisomy }\end{array}$ \\
\hline $\begin{array}{l}\text { de Grouchy- } \\
\text { Turleau's } \\
\text { Classific.\# }\end{array}$ & Frce trisomy 21 & Translocalion trisomy 21 & Mosaic DS & $\begin{array}{l}\text { - Partial trisomy } \\
\text { - Asociation } \\
\text { trisomy }\end{array}$ \\
\hline
\end{tabular}

* from Epstein ${ }^{7}$

+ from Hamerion $^{2}$

\# from de Grouchy and Turlcau ${ }^{10}$ 
This new proposed classification of the Down syndrome fit the newest International Classification of Diseases of the WHO (WHO-ICD 10), nearly $100 \% .^{11}$ Down syndrome in this ICD are grouped in 4 classes that are Q90.0 for trisomy 21, meiotic non-disjunction, Q90.1 for trisomy 21, mosaic or mitotic non-disjunction, Q90.2 trisomy 21, translocation and Q90.9 for unspecified Down syndrome. The first and the fourth class in the ICD fit into the primary and the guarternary DS of the new classification. While the second and the third class in the ICD fit into the tertiary and the secondary DS of this new classification. The secondary and tertiary DS in this classification are the same as proposed by Hamerton ${ }^{2}$ and also by de Grouchy and Turleau. $^{10}$

There were no explanation why the WHO made their classification in such a way. Lack of a medical geneticist in the ICD-10 team especially in the subteam for congenital malformation, and they didn't make any consultation to a medical geneticist, might be the explanation. As already discussed, the primary and secondary DS in this new classification, have very similar clinical picture, while the tertiary DS has a variable spectrum of clinical picture.

\section{CONCLUSION}

Two hundred and eighty patients from 283 (98.94\%) clinically suspected as Down syndrom (DS) were proven cytogenetically as having trisomy 21 . Only $1.06 \%$ was misdiagnosed as Down syndrome. The primary or regular DS was found in 229 patients or $81.79 \%$, which was lower than expected (93-96\%). The secondary or translocation DS was found in 4 patients $(1.43 \%)$, and was slightly below the expected (2-5\%). The tertiary or mosaic DS was higher (47 patients or $16.78 \%)$ than expected $(2-4 \%)$. This result need to be studied further, and combined to reports from other centres to get a higher number of patients with DS.

This new proposed classification has the same 4 classes of DS as the WHO-ICD 10 and fits it quite well. Furthermore, it is more practical and beneficial for counseling.

\section{REFERENCES}

1. Vogel F, Motulsky AG. Human Genetics. Problems and approaches. Berlin : Springer Verlag, 1986.

2. Hamerton Л. Human Cytogenetics. Clinical Cytogenetics. New York : Academic Press, 1971.

3. Gelehrter TD, Collins FS. Principals of Medical Genetics. Baltimore : Williams-Wilkins, 1990.

4. Antonarakis SE, Petersen MB, MCInnis MG, Adelsberger PA, Schinzel AA, Binkert F, et al. The meiotic stage of nondisjunction in trisomy 21 : determination by using DNA polymorphisms. Am J Hum Genet 1992; 50 : 544.

5. Branholm IB, Degerman EA. Life satisfaction and activity preferences in parents of Down's syndrome children. Scand J Soc Med 1992; $20: 37$ (abstr.).

6. Cortes F, Alliende M, Curotto B. Cytogenetic finding in patient with Down syndrome. Rev Chil Pediatr 1990; $6: 313$ (abstr.).

7. Epstein CJ. Down syndrome (Trisomy 21). In : Scriver CR, Beaudet AR, Sly WS, Valle D, editors. The Metabolic Basis of Inherited Disease. New York: McGraw-Hill, 1989.

8. Verma IC, Mathew S, Elango R, Shukla A. Cytogenetic studies in Down syndrome. Indian Pediatr 1991; 28 : 991 (abstr.).

9. Adiwinata J. Kromosom yang hilang pada pemrosesan menurut modifikasi cara van Hemmel [Magister Thesis]. Jakarta : Faculty of Post-graduate Studies University of Indonesia, 1987.

10. Grouchy de J, Turleau C. Clinical atlas of human chromosome. 2nd ed. New York : Willey \& Sons, 1984.

11. WHO. ICD - 10. Geneva : WHO, 1992. 